\title{
Antibacterial Activity Extract of Leaves of Kaffir Lime (Citrus hystrix DC) Againts of Staphylococcus aureus Bacteria
}

\section{Aktivitas Antibakteri Ekstrak Daun Jeruk Purut (Citrus hystrix DC) Terhadap Bakteri Staphylococcus aureus}

\author{
Siti maimunah ${ }^{1^{*}}$, Raihana ${ }^{1}$, Yosy Cinthya Eriwaty Silalahi ${ }^{1}$ \\ Program Studi Farmasi, Fakultas Farmasi dan Ilmu Kesehatan Universitas Sari Mutiara \\ Indonesia, Medan. Jalan Kapten Muslim N0. 79 Medan 20123 \\ *Email : siti_mai09@yahoo.com
}

Diterima 06 Juni 2020 dan Disetujui 21 Agustus 2020

\begin{abstract}
Abstrak
Jeruk purut (Citrus hystrix DC) adalah jenis tanaman dari suku Rutaceae yang digunakan sebagai antibakteri. Tanaman merupakan tumbuhan asli Indonesia, yang mengandung flavonoid, tanin, getah, alkaloid, dan minyak esensial. Tujuan penelitian ini untuk menentukan kemampuan ekstrak daun Jeruk purut (Citrus hystrix DC) sebagai antibakteri terhadap Staphylococcus aureus dan untuk mengetahui konsentrasi yang paling efektif dalam menghambat bakteri Staphylococcus. Penelitian menggunakan daun jeruk purut yang dikeringkan dengan oven pada suhu $45^{\circ} \mathrm{C}$, pulverizing oleh ukuran 40 , dan ekstraksi selama 5 hari dengan maserasi ethanol $96 \%$. Penelitian ini menggunakan desain rancangan acak lengkap (RAL) dengan variasi konsentrasi $5 \%, 10 \%, 15 \%$, dan 20\%, kemudian digunakan untuk menguji aktivitas antibakteri dengan perbedaan disc diffiusion. Zona hambat terbentuk dari ekstrak dengan konsentrasi 5\% (6,7 $\mathrm{mm}), 10 \%(6,8 \mathrm{~mm}), 15 \%(7,3 \mathrm{~mm})$, dan $20 \%(8,3 \mathrm{~mm})$. Hasil analisis data menunjukkan bahwa daun jeruk purut mempengaruhi pertumbuhan Staphylococcus aureus, dimana berdasarkan penelitian nilai sig $<0,05$ memperoleh nilai dari sig. 0,000 , dan konsentrasi $20 \%$ merupakan yang paling efektif dalam menghambat pertumbuhan dari Staphylococcus aureus sebesar $8,3 \mathrm{~mm}$. Ekstrak daun jeruk purut memiliki aktivitas antibakteri. Ekstrak daun jeruk purut dengan konsentrasi 20\% merupakan konsentrasi efektif untuk menghambat bakteri.
\end{abstract}

Keywords: Citrus hystrix, ekstrak, antibakteri, Staphylococcus aureus.

\section{Abstract}

Kaffir lime (Citrus hystrix DC) is citrus plant of Rutaceae's family that was used as an antibacterial. This plant is native to Indonesia, which contains flavonoids, tannins, saponins, alkaloids, and essential oil. This study aimed to determine the ability of antibacterial extract lime leaves against $\mathrm{S}$. aureus and to find out the concentration that is most effective in inhibiting bacteria S. aureus. The research used lime leaves. By drying the leaves at the oven at temperature $45^{\circ} \mathrm{C}$, pulverizing by mesh 40, and extraction by maceration for 5 days with ethanol $96 \%$. This study used a completely randomized design with treatments in various concentrations of $5 \%, 10 \%$, $15 \%$, and $20 \%$ concentration was then used to test the antibacterial activity with disc diffusion. Inhibition zone formed from extracts with concentration of $5 \%(6,7 \mathrm{~mm}) 10 \%(6,8 \mathrm{~mm}) 15 \%(7,3$ $\mathrm{mm})$ and $20 \%(8,3 \mathrm{~mm})$. The results of the data analysis showed that the administration of lime leaves extract affected the growth of $\mathrm{S}$. aureus, where the value of sig $<0,05$ obtained a value of sig 0,000. Based on the research, among the others, the concentration of $20 \%$ was that the most effective in inhibiting the growth of S. aureus that was $8,3 \mathrm{~mm}$. Kaffir lime (Citrus hystrix DC.) leaf extract has antibacterial activity against the S. aureus. Concentration extract $20 \%$ is an effective concentration to inhibit bacterial.

Keywords : Citrus hystrix, extract, antibacterial, Staphylococcus aureus 


\section{PENDAHULUAN}

Tanaman jeruk purut berasal dari Asia Timur, Asia Tenggara (Agusta, 2000). Di Asia Tenggara terdapat diantaranya di Indonesia memiliki pusat keragaman hayati yang menduduki urutan terkaya di dunia setelah Brazil. Diantaranya sekitar 40.000 spesies tumbuhan, dari seluruh spesies tumbuhan tersebut \pm 9.600 spesies tumbuhan berkhasiat obat dan \pm 300 spesies yang dimanfaatkan sebagai obat tradisional (Depkes RI, 2006).

Di Indonesia banyak masyarakat yang menanam jeruk purut (Citrus hystrix) di pekarangan atau di kebun. Merupakan tanaman perdu, bentuk buahnya bulat dengan tonjolan-tonjolan, permukaan kulitnya kasar, tebal dan mengeluarkan aroma khas. Karena banyak yang menanamnya sehingga jeruk purut banyak dijumpai di setiap kota yang ada di Indonesia. Tanaman ini berasal dari genus Citrus yang menghasilkan minyak atsiri. Buah dan daunnya biasa digunakan oleh masyarakat untuk bumbu penyedap masakan. Daun jeruk purut memiliki kandungan senyawa antibakteri seperti alkaloid, flavonoid, dan tannin (Miftahendarwati, 2014).

Yuliani et al., (2011), menyatakan bahwa kandungan minyak atsiri yang terdapat di daun jeruk purut mampu menghambat pertumbuhan dan membunuh Staphylococcus aureus dan E. coli. Minyak atsiri dengan konsentasi 2\% dan $1 \%$ sudah dapat menghambat pertumbuhan Staphylococcus aureus. Konsentrasi minyak atsiri $1 \%$ merupakan konsentrasi terkecil yang mampu menghambat pertumbuhan Staphylococcus aureus sehingga konsentrasi tersebut dinyatakan sebagai KHM.

Dhavesia (2017) menyatakan bahwa uji aktivitas antibakteri ekstrak daun jeruk purut dengan konsentrasi ekstrak 50\% memiliki luas zona hambat yang lebih besar dibandingkan dengan konsentrasi ekstrak 12,5 dan 25\% yaitu dengan rata-rata luas zona hambat terhadap kedua bakteri yaitu $1,593 \mathrm{~cm}^{2}$. Luas zona hambat ekstrak dengan konsentrasi 50\% terhadap Staphylococcus epidermis adalah $1,251 \mathrm{~cm}^{2}$ dan Pseudomonas aeruginosa adalah $1,934 \mathrm{~cm}^{2}$. Konsentrasi ekstrak $12,5 \%$ memiliki rata-rata luas zona hambat sebesar $0,561 \mathrm{~cm}^{2}$, dan konsentrasi $50 \%$ memiliki rata-rata luas zona hambat sebesar 0,984 $\mathrm{cm}^{2}$ (Dimenta et al., 2020).

Staphylococcus aureus merupakan bakteri Gram positif berbentuk bulat, berdiameter $1 \mu \mathrm{m}$ tersusun berkelompok seperti anggur yang tidak teratur. Staphylococcus aureus bersifat aerobik atau mikroaerofilik. Berkembang dengan cepat dengan suhu $37^{\circ} \mathrm{C}$, dapat membentuk pigmen pada suhu $20-35^{\circ} \mathrm{C}$. Bakteri tersebut membentuk koloni abu-abu hingga kuning emas (Jawetz, 2008). Pada media, koloninnya berbentuk bulat, diameter 1-2 mm, cembung, buram, mengkilat dan konsistensinya lunak (Syahrurahman et al., 2010). Dengan adanya senyawa flavanoid yang berfungsi sebagai antibakteri, peneliti tertarik untuk melakukan penelitian uji aktivitas antibakteri ekstrak daun jeruk purut (Citrus hystrix) terhadap bakteri Staphylococcus aureus.

\section{METODE}

Jenis penelitian ini adalah eksperimental. dilakukan di Laboratorium Mikrobiologi Fakultas Farmasi Universitas Sari Mutiara Indonesia, Medan. Sampel yang digunakan adalah daun jeruk purut (Citrus hystrix), berasal dari daerah Paloh Lada, Kecamatan Dewantara, Kabupaten Aceh Utara. Diambil secara purposif, yang 
didasarkan atas pertimbangan bahwa populasi sampel adalah homogen dan sampel yang dianalisis dianggap sampel yang representatif. Ekstrak yang digunakan untuk uji aktivitas antibakteri pada konsentrasi 5\%,10\%,15\%, dan 20\% dengan metode difusi cakram. Identifikasi sampel daun jeruk purut (Citrus hystrix) dilakukan di Herbarium Medanense (MEDA) Universitas Sumatera Utara.

\begin{abstract}
Alat dan Bahan
Alat yang digunakan dalam penelitian ini adalah aluminium foil, autoklaf, blender, cawan petri, inkubator, jangka sorong, jarum ose, kertas perkamen, kertas saring, kapas, kassa steril, lemari pendingin, lemari pengering, timbangan, neraca listrik, laminar air flow, oven, pencadang logam, pemanas air, pinset, mikropipet, lampu bunsen, kertas cakram, hot plate. Bahan yang digunakan adalah ekstrak daun jeruk purut (Citrus hystrix). Nutrient agar, Staphylococcus aureus, akuades, etanol 96\%, Standart Mc. Farland, Kloramfenikol.
\end{abstract}

\title{
Penyiapan Sampel
}

Sampel daun jeruk purut yang masih segar dikumpulkan sebanyak $3 \mathrm{~kg}$, disortasi basah, dicuci bersih dibawah air yang mengalir dan ditiriskan, selanjutnya dikeringkan di oven pada suhu $45^{\circ} \mathrm{C}$ hingga meremah, dan kemudian dijadikan serbuk dengan ukuran mesh 40 (dengan modifikasi metode Miftahendrawati, 2014).

\section{Pembuatan Ekstrak Daun Jeruk Purut (Citrus hystrix)}

Ekstrak daun jeruk purut sebanyak $200 \mathrm{~g}$ dimaserasi menggunakan pelarut etanol $96 \%$. Simplisia direndam dalam pelarut sebanyak $2000 \mathrm{ml}$ (perbandingan 1:10) selama 5 hari pada suhu ruang $\left(27^{\circ} \mathrm{C}\right)$. Selanjutnya hasil yang diperoleh disaring. Maserat yang diperoleh, ditampung dan diuapkan untuk memisahkan pelarutnya. Penguapan dilakukan dengan menggunakan rotary evaporator, kemudian di dapat ekstrak kental (dengan modifikasi Miftahendrawati, 2014).

\section{Pembuatan Variasi Konsentrasi Ekstrak Daun Jeruk Purut}

Ekstrak kental yang diperoleh kemudian dibuat dengan berbagai konsentrasi. Konsentrasi ekstrak daun jeruk purut yang digunakan sebagai berikut: 5\%, 10\%, 15\% dan 20\%. Ekstrak daun jeruk purut dengan konsentrasi 5\%. Ditimbang sebanyak 0,5 g ekstrak kental daun jeruk purut kemudian dicukupkan dengan etanol $10 \mathrm{ml}$. Ekstrak daun jeruk purut dengan konsentrasi 10\%. Ditimbang sebanyak $1 \mathrm{~g}$ ekstrak kental daun jeruk purut kemudian dicukupkan dengan etanol $10 \mathrm{ml}$. Ekstrak daun jeruk purut dengan konsentrasi $15 \%$. Ditimbang sebanyak 1,5 g ekstrak kental daun jeruk purut kemudian dicukupkan dengan etanol $10 \mathrm{ml}$. Ekstrak daun jeruk purut dengan konsentrasi 20\%. Ditimbang sebanyak 2 g ekstrak kental daun jeruk purut kemudian dicukupkan dengan etanol $10 \mathrm{ml}$.

Kontrol Positif. Kloramfenikol digunakan sebagai kontrol positif. Kadar yang sensitif terhadap bakteri uji yaitu $30 \mu \mathrm{g}$. Pembuatannya dengan $30 \mathrm{mg}$ kloramfenikol dilarutkan dalam $10 \mathrm{ml}$ (Widiastuti, 2016).

Sterilisasi Alat. Alat-alat yang digunakan dalam uji aktivitas antibakteri ini, disterilkan terlebih dahulu sebelum dipakai. Alat-alat gelas disterilkan didalam oven pada suhu $170^{\circ} \mathrm{C}$ selama $1 \mathrm{jam}$. Media disterilkan di autoklaf pada suhu $121^{\circ} \mathrm{C}$ selama 15 menit. Jarum ose dan pinset dengan lampu bunsen (Lay, 1994). 
Pembuatan Media Agar Miring (NA). Sebanyak 28 g nutrient agar dilarutkan dalam air suling steril ditambahkan $1000 \mathrm{ml}$ kemudian dipanaskan hingga semua larut, dalam keadaan panas larutan tersebut kemudian dimasukan kedalam erlenmayer, lalu disterilkan di autoklaf selama 15 menit pada suhu $121^{\circ} \mathrm{C}$ (Oxoid, 2013).

\section{Inokulasi Bakteri Staphylococcus aureus Pada Media Agar Miring}

Bakteri uji diambil dengan jarum ose steril, lalu ditambahkan pada media agar miring dengan cara menggores. Selanjutnya diinkubasi dalam inkubator pada suhu $37^{\circ} \mathrm{C}$ selama 24 jam (Siregar, 2009).

\section{Pembuatan Standar Kekeruhan Larutan (Larutan Mc. Farland).}

Sebanyak 99,5 ml larutan asam sulfat $1 \% \mathrm{v} / \mathrm{v}$ dan $0,5 \mathrm{ml}$ larutan Barium Klorida $1,175 \% \mathrm{~b} / \mathrm{v}$, dicampurkan kedua larutan di atas dalam tabung reaksi dan divortex sampai homogen. Sehingga diperoleh suspensi dengan tingkat kekeruhan yang dikenal dengan kekeruhan Mc. Farland. Apabila kekeruhan suspensi bakteri uji sama dengan kekeruhan suspensi Mc. Farland, maka konsentrasi suspensi bakteri uji adalah $10^{8}$ $\mathrm{CFU} / \mathrm{ml}$ (Victor, 1980).

\section{Pembuatan Suspensi Bakteri Uji}

Bakteri yang telah diinokulasi diambil dengan kawat ose steril lalu disuspensikan kedalam tabung yang berisi $2 \mathrm{ml}$ larutan $\mathrm{NaCl} 0,9 \%$ hingga diperoleh kekeruhan yang sama dengan standar kekeruhan larutan Mc.Farland (Mplia, 2012).

\section{Uji Aktivitas Antibakteri Pada Ekstrak Daun Jeruk Purut Terhadap Stpahylococcus aureus}

Sterilkan semua alat dan bahan yang akan dipakai. Uji aktivitas antibakteri dilakukan dengan metode difusi agar menggunakan kertas cakram (paper disc). Uji aktivitas antibakteri dilakukan secara triplo. Kertas cakram dicelupkan ke dalam sampel dengan konsentrasi 5\%,10\%,15\% dan 20\%, kemudian diletakan di atas media NA yang telah diinokulasikan dengan bakteri uji. Inkubasi dilakukan dengan suhu $37^{\circ} \mathrm{C}$ selama 24 jam. Pengamatan dilakukan terhadap terbentuknya zona hambat di sekitar kertas cakram. Antibiotik kloramfenikol digunakan sebagai pembanding yang dilihat zona hambatnya pada mikroba uji (Waluyo, 2010).

\section{HASIL DAN PEMBAHASAN}

\section{Hasil Ekstraksi Daun Jeruk Purut}

Penelitian menggunakan daun jeruk purut yang segar sebanyak $3 \mathrm{~kg}$ dan berat daun kering 600 gram. Serbuk daun jeruk purut (Citrus hytrix) sebanyak 200 gram dimaserasi dengan 2 liter etanol 96\% hasil rendemen 1,5 L dan hasil rotary ovaporator diperoleh ekstrak kental sebanyak 19,89 gram. Warna ekstrak kental hijau tua. Hasil ekstrak daun jeruk purut dapat dilihat pada gambar 1.

\section{Uji Aktivitas Antibakteri Terhadap Staphylococcus aureus.}

Sebanyak $10 \mathrm{ml}$ media NA dituang secara aseptik ke dalam cawan Petri, setelah memadat diinokulasikan $0,1 \mathrm{ml}$ suspensi bakteri Staphylococcus aureus. Uji aktivitas antibakteri dilakukan dengan metode difusi agar yaitu dengan menempelkan kertas cakram yang telah direndam pada masing-masing konsentrasi ekstrak daun jeruk purut $5 \%, 10 \%, 15 \%$, dan $20 \%$ ke dalam cawan Petri yang berisi media NA yang sudah diinokulasikan bakteri Staphylococcus aureus tersebut. Aktivitas antibakteri ditentukan 
dengan mengukur zona hambat yang terbentuk disekitar kertas cakram, setelah masa inkubasi setiap 1 x 24 jam selama 3 hari pengukuran zona hambat.

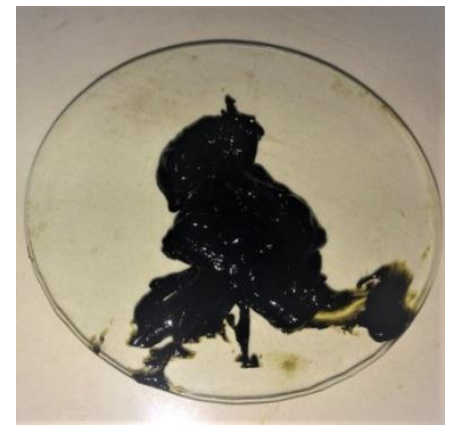

Gambar 1. Hasil Ekstraksi Daun Jeruk Purut (Citrus hystrix).

Hasil uji aktivitas antibakteri (Gambar 2.) menunjukkan bahwa pada hari ke-1 tidak terdapat zona hambat pada sekitaran kertas cakram. Kloramfenikol sebagai kontrol positif dengan perlakuan ekstrak daun jeruk purut berbeda secara nyata dan memiliki zona hambat yang paling besar sebesar 22,4 $\mathrm{mm}$. Dalam hal ini kloramfenikol bersifat bakteriostatik.

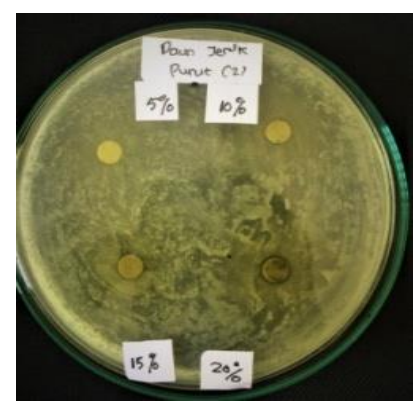

A

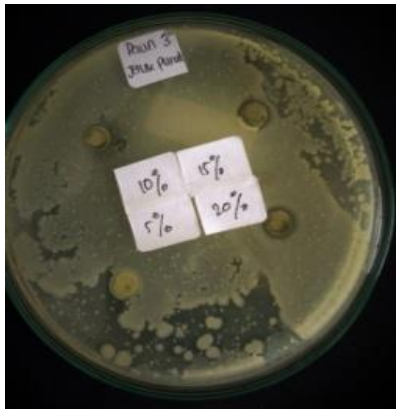

C

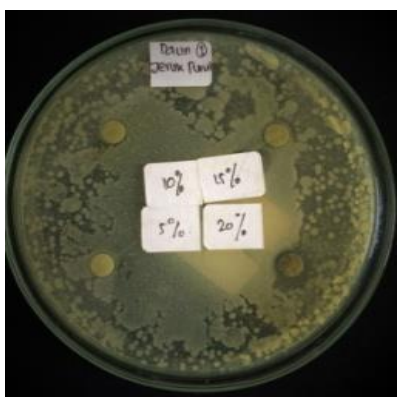

B

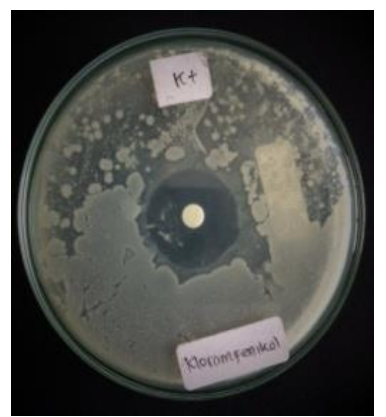

$\mathrm{D}$

Gambar 2. Hasil Pengujian Aktivitas Antibakteri Ekstrak Daun Jeruk Purut Terhadap Staphylococcus aureus (a) Pengulangan I; (b) Pengulangan II; (c) Pengulangan III; (d) Kloramfenikol

Setelah diamati $2 \times 24$ jam pada isolat bakteri Staphylococcus aureus tidak terdapat pertumbuhan di area zona hambat pada cakram yang sudah diberi ekstrak daun jeruk purut dengan berbagai konsentrasi. Hal ini menunjukan bahwa ekstrak daun jeruk purut dapat menghambat bakteri (bakterisid). Efek Bakteriostatik hanya menghambat 
pertumbuhan sel, hanya menghambat sintesis protein bakteri, Efek bakteriosida akan mematikan sel bakteri tersebut, namun tidak terjadi lisis sel. Sedangkan, efek bakteriolitik akan mematikan sel bakteri serta terjadi lisis sel, menghambat dinding sel bakteri tersebut. Apabila diberi konsentrasi yang tinggi dan masa inkubasi yang lama akan membunuh bakteri tersebut. (Madigan et al., 2009). Dari penjelasan tersebut dapat disimpulkan ekstrak daun jeruk purut bersifat bakteriostatik, bakteriosida, dan bakteriolitik yang memiliki aktifitas menghambat pertumbuhan bakteri Staphylococcus aureus. Hasil pengujian aktivitas antibakteri ekstrak daun jeruk purut terhadap bakteri Staphylococcus aureus bisa dilihat pada Tabel 1.

Tabel 1. Rata- rata Diameter Zona Hambat Perhari $(\mathrm{mm})$ dalam Pengamatan per 24 jam selama 3 hari.

\begin{tabular}{cccc}
\hline \multirow{2}{*}{ Konsentrasi } & \multicolumn{3}{c}{ Rata-rata Diameter Zona hambat Per hari (mm) } \\
& Hari ke-1 & Hari ke-2 & Hari ke-3 \\
\hline $5 \%$ & 0 & 6,6 & 6,7 \\
$10 \%$ & 0 & 6,8 & 6,8 \\
$15 \%$ & 0 & 7,3 & 7,3 \\
$\mathbf{2 0} \%$ & $\mathbf{0}$ & $\mathbf{8 , 2}$ & $\mathbf{8 , 3}$ \\
\hline Kloramfenikol & 22,4 & 25,5 & 26,2 \\
\hline
\end{tabular}

Efek antibakteri yang paling baik terlihat pada konsentrasi ekstrak $20 \%$ pada bakteri Staphylococcus aureus. Perubahan rata-rata diameter zona hambat pertumbuhan baktri dapat dilihat pada Gambar 3.

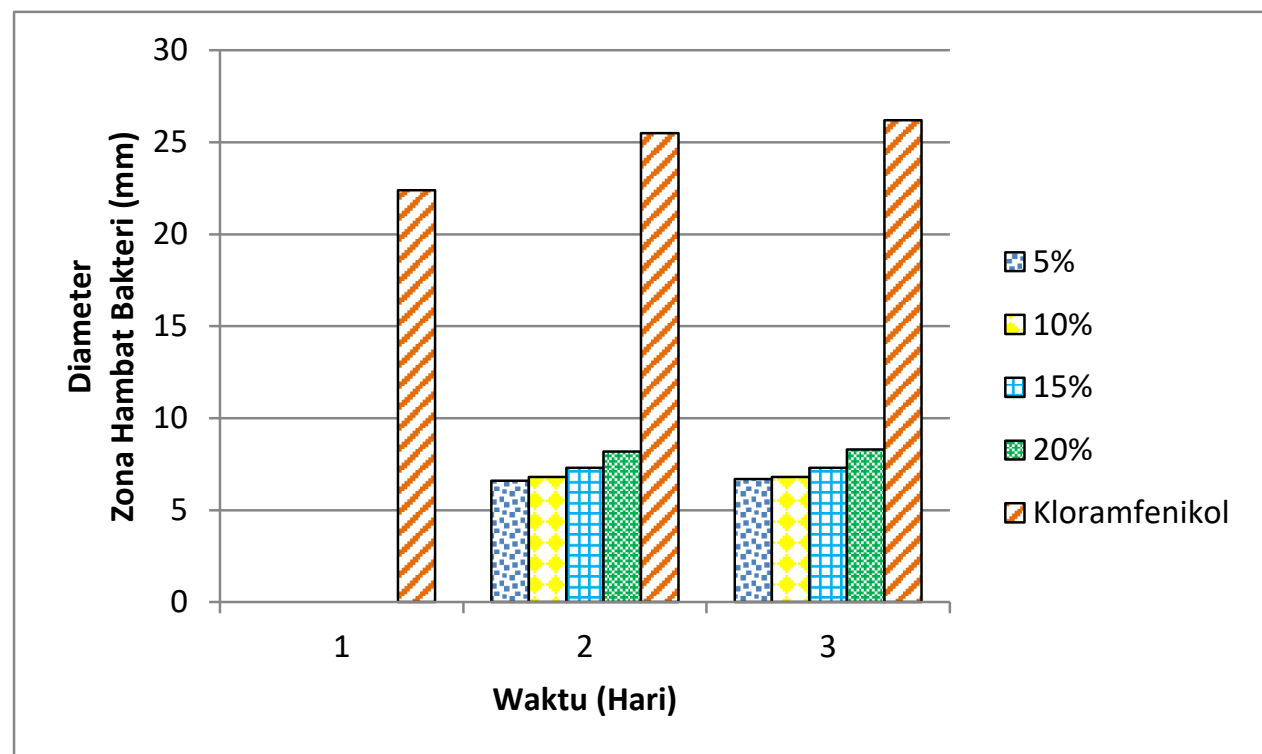

Gambar 3. Hasil Rata-Rata Diameter Zona Hambat Per hari (mm) dalam 3 hari pengamatan

Menurut Davis \& Stout (1971), jika diameter zona hambat $5 \mathrm{~mm}$ atau kurang maka aktivitas penghambatan dikategorikan lemah, diameter zona hambat 6-10 $\mathrm{mm}$ maka dikategorikan sedang, diameter zona hambat sebesar 11-20 $\mathrm{mm}$ maka 
dikategorikan kuat dan jika diameter $21 \mathrm{~mm}$ atau lebih maka aktivitas penghambatan dikategorikan sangat kuat. Pada hari ke-3 menunjukkan bahwa terdapat zona hambat pada konsentrasi $5 \%(6,7 \mathrm{~mm}), 10 \%(6,8 \mathrm{~mm}), 15 \%(7,3 \mathrm{~mm})$, dan $20 \%(8,3 \mathrm{~mm})$.

Menurut Ajizah (2004), selain faktor konsentrasi, jenis bahan antimikroba juga menentukan kemampuan menghambat pertumbuhan kuman. Dalam penelitian ini konsentrasi dan lamanya inkubasi sangat mempengaruhi zona hambat bakteri Staphylococcus aureus. Pada kontrol positif zona hambat pada kertas cakram semakin membesar pada hari ke-2. Berdasarkan hasil pengujian hipotesis diperoleh nilai signifikan dibawah 0,05, maka hipotesis alternatif penelitian diterima, yaitu terdapat pengaruh konsentrasi ekstrak daun jeruk purut terhadap pertumbuhan bakteri Staphylococcus aueus $(\mathrm{F}-$ hitung $=3.633,414$; sig. $=0,000)$.

Pada hari ke-3 terdapat rata-rata zona hambat pada konsentrasi $5 \%(6,7 \mathrm{~mm})$, $10 \%(7,2 \mathrm{~mm}), 15 \%(7,3 \mathrm{~mm})$, dan $20 \%(8,3)$ rata-rata diameter zona hambat dikategorikan sedang. Berdasarkan hasil pengujian hipotesis diperoleh nilai signifikan dibawah 0,05 , maka hipotesis alternatif penelitian diterima, yaitu terdapat pengaruh konsentrasi ekstrak daun jeruk purut terhadap pertumbuhan bakteri Staphylococcus aureus $($ F-hitung $=1.798,674 ;$ sig. $=0,000)$.

Kloramfenikol sebagai kontrol positif berbeda secara nyata yang dapat dilihat pada (Tabel 1.), dengan perlakuan ekstrak daun jeruk purut dan memiliki nilai zona hambat paling besar. Kloramfenikol memiliki diameter zona hambat sebesar 26,2 $\mathrm{mm}$ sehingga dikategorikan sangat kuat. Hal ini dapat terjadi karena kloramfenikol adalah antibiotik yang sudah lazim digunakan dalam pengobatan penyakit yang disebabkan oleh bakteri dengan kandungan senyawa aktif yang sudah teruji. Namun penggunaan kloramfenikol dibatasi karena dapat merusak ribosom mitokondria pada sel mamalia.

Pemilihan kloramfenikol sebagai kontrol positif didasari karena bakteri Staphylococcus aureus telah banyak mengalami resistensi terhadap beberapa antibiotik selain itu antibiotik ini bersifat bakteriostatik yaitu kemampuan untuk menghambat pertumbuhan bakteri tanpa mematikannya dengan spektrum luas yang aktif terhadap bakteri gram positif, menggangu proses sintesis protein bakteri, mampu menghambat perlekatan asam amino dari bakteri sehingga dapat menghambat bakteri Staphylococcus aureus. Penelitian ini juga pernah dilakukan Dhavesia (2017) pada ekstrak daun jeruk purut (Citrus hystrix) dimana diketahui terdapat aktivitas antibakteri terhadap bakteri Pseudomonas aeruginosa memiliki zona hambat $0,605 \mathrm{~cm}^{2}, 1,132 \mathrm{~cm}^{2}, 1,934 \mathrm{~cm}^{2}$ dengan konsentrasi $12,5 \%$, 25\%, dan 50\%, dan Staphylococcus epidermidis memiliki zona hambat $0,518 \mathrm{~cm}^{2}, 0,837 \mathrm{~cm}^{2}$ dan $1,251 \mathrm{~cm}^{2}$ pada konsentrasi $12,5 \%, 25 \%$ dan $50 \%$.

Daun jeruk purut mampu menghambat pertumbuhan bakteri (Chueahongtong et al., 2011). Hal ini disebabkan adanya kandungan tanin 1,8\%, steroid triterpenoid, dan minyak atsiri 1-1,5\% (Dalimartha, 2000). Aktivitas antibakteri yang terdapat pada daun jeruk purut berasal juga dari unsur flavanoid dan tanin yang terkandung di dalamnya, flavanoid menyebabkan terjadinya kerusakan permebailitas dinding sel bakteri, mikrosom, dan lisosom sebagai hasil interaksi antara flavanoid dengan DNA bakteri (Sabir, 2005). Tanaman yang mengandung alkaloid dapat menghambat pertumbuhan bakteri Gram positif maupun Gram negatif. Flavonid berfungsi sebagai antibakteri dengan menghambat fungsi membran sitoplasma. Saponin berperan sebagai antibakteri dengan mekanisme merusak permeabilitas dinding sel sehingga dapat menimbulkan kematian sel. Tanin memiliki fungsi mempresipitasi protein sehingga mengaruhi peptidoglikan bakteri, pada daun jeruk purut mengandung tanin sebanyak 1,8\%. Tanin juga menggangu fungsi sitoplasma dan membran plasma, meghambat fungsi enzim, dan menghilangkan substrat yang dibutuhkan untuk pertumbuhan bakteri. Tanin merupakan senyawa polar. Bakteri Staphylococcus aureus memiliki dinding sel yang bersifat polar sehingga tanin yang juga bersifat polar dapat menembus dinding sel 
bakteri. Dinding sel berfungsi untuk mempertahankan bentuk sel dan melindungi isi sel. Apabila dinding sel rusak maka hal tersebut akan mengganggu kegiatan dalam sel sehingga sel tersebut juga akan rusak dan mati. Jadi, tanin berfungsi untuk merusak dinding sel bakteri Staphylococcus aureus (Dalimartha, 2000;Kumar et al, 2012; Min et al, 2008; Lino et al, 2011). Tanin merupakan senyawa fenol bekerja dengan cara menghambat pertumbuhan bakteri dengan melakukan denaturasi protein, sehingga permeabilitas bakteri meningkat. Kerusakan dan peningkatan permeabilitas sel bakteri menyebabkan pertumbuhan sel menjadi terhambat dan akhirnya dapat menyebabkan kematian sel (Akiyanma dkk, 2001, dan Ajizah, 2004). Dari hasil penelitian yang telah dilakukan ternyata sesuai dengan hipotesis awal. Bahwasanya ekstrak daun jeruk purut mempunyai aktivitas antibakteri terhadap bakteri Staphylococcus aureus.

\section{KESIMPULAN}

Ekstrak daun jeruk purut (Citrus hystrix CD.) memiliki aktivitas antibakteri terhadap bakteri Staphylococcus aureus. Konsentrasi ekstrak 20\% merupakan konsentrasi yang paling efektif untuk menghambat bakteri Staphylococcus aureus dengan luas zona hambat $8,3 \mathrm{~mm}$.

\section{DAFTAR PUSTAKA}

Ajizah, A, 2004. Sensitivitas Salmonella typhimurium terhadap Ekstrak Daun Psidium guajava L. Bioscientiae. Vol. 1(1) : 31-38.

Akiyanma, H., Fuji K., Yamasuki O., Oone T., Iwatsuki T. 2001. Antibacterial Action of Several Tannin Agains Staphylococcus aureus. J. Antimicrobial Chemotherapy. Vol 48 (2): 487-491.

Chueahongthong, F., Chadarat A., Okonogi S., Tima S., Anuchapreeda S. 2011. Cytotoxic Effects of Crude Kaffir Lime (Citrus hystrix D.C) Leaf Fractional Extracts on leukemic Cell Lines. Journal of Medicinal Plants Research. Vol. 5(14): 3097-3105.

Dalimartha, S. 2000. Atlas Tumbuhan Obat Indonesia. Jakarta: Trubus Agriwidya. 86 Halaman.

Davis, W.W., Stout T.R. 1971. Disc Plate Methods of Microbiological Antibiotic Assay. Microbiology. Hal 659-665.

Depkes RI. 2006. Kotranas. Jakarta: Dapartemen Kesehatan RI. Hal. 1,8.

Mpila, D. A. 2012. Uji Aktivitas antibakteri ekstrak etanol daun mayana (Coleus atropurpureus) Terhadap Staphylococcus aureus, Escherichia coli dan Pseudomonas aeruginosa Secara In-vitro. Manado: Universitas Sam Ratulangi. Hal 16.

Dhavesia, V. 2017. Uji Aktivitas Antibakteri Ekstrak Daun Jeruk Purut (Citus hystrix) terhadap Pseudomonas aeruginosa dan Staphylococcus aureus. Yogyakarta: Universitas Atmajaya.

Jawetz., Melnick., Adelberg. 2010. Mikrobiologi Kedokteran. Edisi 23, Translation of Jawetz, Melnick, and Adelberg's Medical Microbiology. Jakarta. 
Kumar, K.P.S., Bhowmik, D., Duraivel, S. 2012. Traditional and Medical Uses of Banana. Journal Of Pharmacognosy and Phytochemestry. Vol 3(2): 51-63.

Lino, P.B., Correa, C.F., Archondo., Dellova. 2011. Evaluation Of Post-Surgical Healing In Rats Using A Topical Preparation Based On Extract Of Musa sapientum Epicarp. Revista Brasileira De Farmacognosia. Hal: 491-496.

Lay, B.W. 1994. Analisa Mikroba di Laboratorium. Jakarta: Raja Grafindo Persada. Hal. 109.

Madigan, M.T., J.M. Martinko, J. Parker. 2009. Biology ofMicroorganisms. $12^{\text {th }}$ ed. New York: Prentice Hall International.

Martiasih, M., Sidharta B B R., Admojo PK. 2014. Aktivitas Antibakteri Ekstrak Pepaya (Carica papaya L.) Terhadap Escherichia coli dan Streptococcus pyogenes. Jurnal Penelitian, 5-7.

Miftahendarwati. 2014. Efek Antibakteri Ekstrak Daun Jeruk Purut (Citus hystrix) Terhadap Bakteri Staphylococcus mutans (In Vitro). Skripsi FKG Universitas Hasanuddin. Hal: 21-22.

Min, B.R., Pinchak, W.E., Merkel, R., Walker. 2008. Comparative Antimicrobial Activity of Tannin Extract From Pereminal Plants On Mastitis Pathogens. Hal: 66-73.

Mpila. D. A., Fatimawali, Wiyono, W. I. 2012. Uji Aktivitas Antibakteri Ekstrak Etanol Daun Mayana (Coleus atropurpureus (L) Benth. Terhadap Staphylococcus aureus, Escherichia coli Dan Pseudomonas aeruginosa Secara In-Vitro. Skripsi. Fakultas Matematika dan Ilmu Pengetahuan Alam. UNSRAT : Manado.

Oxoid. 2013. Nutrient Agar and Nutrient Browth. England: Oxoid LTD. Hal. 5.

Pratiwi, S.T. 2008. Mikrobiologi Farmasi. Jakarta: Penerbit Erlangga. Hal: 105-117.

Purnawijayanti, H. 2001. Sanitasi, Higiene, dan Keselamatan Kerja dalam Pengolahan Makanan. Kanisius. Yogyakarta.

Syahrurahman. 2010. Buku Ajar Mikrobiologi Kedokteran. Jakarta: Binarupa Aksara Publishers.

Victor, L. 1980. Antibiotics in Laboratory Test. USA: The Williams and Wilkins Company. Hal 125.

Waluyo, L. 2010. Teknik dan Metode dasar dalam mikrobiologi. UMM Press, Malang. Hal. 88.

Widyastuti, R., Nurhaeni, F., Marfuah. D. L., Wibowo. G. S. Al. 2016. Potensi Antibakteri dan Anticandida Ekstrak Etabol Daun Pegagan (Centella asiatica. L. (Urb). Karya Tulis. Politekkes Bhakti Setya Indonesia: Yogyakarta. 
Yuliyani, R., Indrayudha. P., Rahmi, S. S. 2011. Aktivitas Antibakteri Minyak Atsiri Daun Jeruk Purut (Citrus hystix) Terhadap Staphylococcus aureus dan Escherchia coli. Surakarta. Jurnal Pharmacon. Vol. 12(2): 52-58. 